\title{
Vegetative Rescue and Clonal Propagation of Lecythis Pisonis Cambess
}

\author{
Vanessa Pimentel Bernardes ${ }^{1}$ (1) 0000-0001-9103-5361 \\ Elzimar de Oliveira Gonçalves ${ }^{2}$ (D) 0000-0001-7675-2493 \\ Bruna Tomaz Sant'Ana ${ }^{2}$ (D) 0000-0002-9672-3785 \\ Rodrigo Sobreira Alexandre ${ }^{2}$ (1) 0000-0002-5248-6773 \\ Ivar Wendling ${ }^{3}$ (1) 0000-0002-1008-6755
}

\begin{abstract}
Our study sought to evaluate the rooting capacity of indole butyric acid (IBA)-treated stem cuttings and the efficiency of the vegetative rescue technique of adult and transitional parent trees of Lecythis pisonis. Softwood, hardwood, and semi-hardwood leafless cuttings treated with IBA $\left(0 ; 2,000 ; 4,000 ; 6,000\right.$; and 8,000 $\left.\mathrm{mg} \mathrm{kg}^{-1}\right)$ were tested in a randomized block design with four replicates and 10 cuttings per plot. The growth of epicormic shoots was also evaluated in $60-\mathrm{cm}$ branches removed from the tree canopy and kept in greenhouse for 60 days. Cuttings from adult trees did not form roots. Softwood cuttings from transitional trees had a very low rooting percentage. In both cases, no influence of IBA concentrations were observed. The use of the sectioned-branch technique was feasible for inducing sprouts.
\end{abstract}

Keywords: auxin, cutting types, epicormic shoots, Atlantic forest.

\section{INTRODUCTION AND OBJECTIVES}

Sapucaia (Lecythis pisonis Cambess) is a native species to the Atlantic Rainforest and Amazon region (Smith, 2014), which belongs to the Lecythidaceae family. It is suitable for plantations such as agroforestry systems and recovery of degraded areas (Inhetvin, 2010). Studies on the nutritional composition of their nuts such as cashew nut (Anarcadium occidentale Linnaeus) and Brazil nut (Bertholletia excelsa Humboldt \& Bonpland) suggest they can be used for human consumption (Carvalho et al., 2012; Denadai et al., 2007).

Sapucaia propagates mainly by seeds, with sowing occurring as soon as the seeds are extracted from the fruit (Lorenzi, 2008) due to their short viability (Garay et al., 2012).

However, this species has a low natural frequency in the forests and blooms sporadically: some individuals bloom annually, and others each five years (Wickens, 1991). The beginning of its fruiting is delayed, starting on average after 15 years, when the tree achieves 10.8-12.8 $\mathrm{m}$ in height (Rizzini, 1971). Moreover, seeds are fundamental for the food chain, since they are highly sought after by medium and large size animals (Inhetvin, 2010). All these factors contribute to a small annual seed production.

Low production and difficulty in obtaining the seeds make the vegetative propagation by cutting a very interesting technique. The sprouts for the cutting production could be collected from transitional or mature trees, regardless of the fruiting season and avoiding all difficulties of picking the fruits. In addition, cuttings of genotypes with higher fruit productive capacity could be collected from adult trees, which would contribute to the supply of seedlings for plantations designed for nut production.

Several factors affect the rooting of the cuttings, including the parent plant physiological conditions, juvenility, rooting environment conditions, and position and degrees of lignification of the branches (Silva et al., 2011). Rooting capacity can be improved by factors such as the presence of leaves on cuttings, as well as the use of intermittent nebulization and growth regulators (Scaloppi Junior \& Martins, 2014).

The application of plant regulators, mainly of the auxin group, has been considered as a favorable factor for adventitious rooting in several species. The use of indole-3-butyric acid

\footnotetext{
${ }^{1}$ Instituto de Desenvolvimento Florestal e da Biodiversidade do Estado do Pará (Ideflor-Bio), Belém, PA, Brasil

${ }^{2}$ Universidade Federal do Espírito Santo (UFES), Vitória, ES, Brasil

${ }^{3}$ Centro Nacional de Pesquisa de Florestas (Embrapa Florestas), Colombo, PR, Brasil
} 
(IBA) has been shown to be the most effective regulator in most cases (Sauer et al., 2013), especially for forest species.

Our study sought to evaluate the rooting potential of IBAtreated stem cuttings obtained from adult and transitional sapucaia trees, as well as the viability of shoot production on branches removed from adult trees.

\section{MATERIALS AND METHODS}

Branches for cutting production were collected from eight parent trees located in four different municipalities in the state of Espírito Santo (Table 1).

The chemical, physical and organic matter (total organic carbon) characterization of the soil was conducted in threepoint samples collected with a screw type soil auger in the crown projection area of the trees, at the depth of $0-20 \mathrm{~cm}$. The results (Table 2) indicated that, in general, the trees were located in fertile soils with a good nutritional balance for the plants (Alvarez et al., 1999).

Our study was conducted from October 2015 to April 2016 in a greenhouse at the experimental area of the Forest Sciences and Wood Department of the Universidade Federal do Espírito Santo (DCFM-CCAE-UFES), located in the municipality of Jerônimo Monteiro, ES. The experimental area is located between the coordinates $20^{\circ} 47^{\prime} 30.3^{\prime \prime}$ South Latitude and $41^{\circ} 23^{\prime} 21.8^{\prime}$ ' West Longitude.

According to the Köppen International classification, the predominant climate in the region is Cwa, with rainy summer and cold and dry winter, with average temperature of $23.1^{\circ} \mathrm{C}$, and $1341 \mathrm{~mm}$ total average rainfall (Lima et al., 2008).

Table 1. General characteristics and location of the selected parent trees in different municipalities of the state of Espírito Santo, in 2015.

\begin{tabular}{|c|c|c|c|c|c|}
\hline $\begin{array}{l}\text { Parent tree/ } \\
\text { coordinate }\end{array}$ & Municipality & $\begin{array}{l}\text { Total height } \\
\text { (m) }\end{array}$ & $\begin{array}{c}\text { Branch height } \\
\text { (m) }\end{array}$ & $\begin{array}{c}\text { Chronological age } \\
\text { (years) }\end{array}$ & Ontogenetic age \\
\hline $\begin{array}{c}\text { M1J } \\
20^{\circ} 74^{\prime} 30^{\prime \prime} \text { Lat. } \\
41^{\circ} 23^{\prime} 21^{\prime \prime} \text { Long. }\end{array}$ & Jerônimo Monteiro & 4 & 2 & 6 & Transitional \\
\hline $\begin{array}{c}\text { M2J } \\
20^{\circ} 47^{\prime} 46^{\prime \prime} \text { Lat. } \\
41^{\circ} 24^{\prime} 22^{\prime \prime} \text { Long. }\end{array}$ & Jerônimo Monteiro & 2.5 & 0.5 & 6 & Transitional \\
\hline $\begin{array}{c}\text { M1C } \\
20^{\circ} 45^{\prime} 14^{\prime \prime} \text { Lat. } \\
41^{\circ} 17^{\prime} 29^{\prime \prime} \text { Long. }\end{array}$ & Cachoeiro de Itapemirim & 13 & 3.2 & 20 to $25^{*}$ & Adult \\
\hline $\begin{array}{c}\text { M2C } \\
20^{\circ} 45^{\prime} 10^{\prime \prime} \text { Lat. } \\
41^{\circ} 17^{\prime} 25^{\prime \prime} \text { Long. }\end{array}$ & Cachoeiro de Itapemirim & 13 & 6.2 & 20 to $25^{*}$ & Adult \\
\hline $\begin{array}{c}\text { M1A } \\
20^{\circ} 43^{\prime} 01^{\prime \prime} \text { Lat. } \\
41^{\circ} 26^{\prime} 05^{\prime \prime} \text { Long. }\end{array}$ & Alegre & 13 & 4.5 & 25 to $30^{*}$ & Adult \\
\hline $\begin{array}{c}\text { M2A } \\
20^{\circ} 43^{\prime} 05^{\prime \prime} \text { Lat. } \\
41^{\circ} 26^{\prime} 13^{\prime \prime} \text { Long. }\end{array}$ & Alegre & 16 & 6.5 & 25 to $30^{*}$ & Adult \\
\hline $\begin{array}{c}\text { M1L } \\
19^{\circ} 08^{\prime} 11^{\prime \prime} \text { Lat. } \\
40^{\circ} 03^{\prime} 30^{\prime \prime} \text { Long. }\end{array}$ & Linhares & 15 & 7.5 & 27 & Adult \\
\hline $\begin{array}{c}\text { M2L } \\
19^{\circ} 08^{\prime} 12^{\prime \prime} \text { Lat. } \\
40^{\circ} 03^{\prime} 31^{\prime} \text { Long. }\end{array}$ & Linhares & 14 & 8 & 27 & Adult \\
\hline
\end{tabular}

* Age estimation; the actual age of the trees are unknown, since there are no records of the plantings.

Table 2. Chemical and physical characteristics of soil collected from the crown projection area of the sapucaia trees, in different municipalities of the state of Espírito Santo, 2015.

\begin{tabular}{|c|c|c|c|c|c|c|c|c|}
\hline \multirow{2}{*}{ Characteristic } & \multicolumn{8}{|c|}{ Parent tree } \\
\hline & M1J & M2J & M1C & M2C & M1A & M2A & M1L & M2L \\
\hline \multicolumn{9}{|l|}{ Physical } \\
\hline Clay (\%) & 0.00 & 16.00 & 28.00 & 35.00 & 55.00 & 38.00 & 15.00 & 15.00 \\
\hline
\end{tabular}


Table 2. Continued...

\begin{tabular}{|c|c|c|c|c|c|c|c|c|}
\hline \multirow{2}{*}{ Characteristic } & \multicolumn{8}{|c|}{ Parent tree } \\
\hline & M1J & M2J & M1C & M2C & M1A & M2A & M1L & M2L \\
\hline Silt (\%) & 24.00 & 5.00 & 17.00 & 7.00 & 10.00 & 13.00 & 3.00 & 2.00 \\
\hline Sand (\%) & 76.00 & 79.00 & 55.00 & 58.00 & 35.00 & 49.00 & 82.00 & 83.00 \\
\hline \multicolumn{9}{|l|}{ Chemical } \\
\hline Phosphorus (mg dm ${ }^{3}$ ) & 18.91 & 7.63 & 75.61 & 36.20 & 51.57 & 43.89 & 8.11 & 11.18 \\
\hline Potassium $\left(\mathrm{mg} \mathrm{dm}^{3}\right)$ & 97.00 & 97.00 & 103.00 & 144.00 & 292.00 & 284.00 & 79.00 & 94.00 \\
\hline Sodium $\left(\mathrm{mg} \mathrm{dm}^{3}\right)$ & 12.00 & 4.00 & 0.00 & 14.00 & 11.00 & 54.00 & 7.00 & 8.00 \\
\hline Calcium $\left(\mathrm{cmoc} \mathrm{dm}^{3}\right)$ & 1.81 & 1.01 & 12.86 & 4.60 & 3.98 & 5.06 & 3.35 & 1.32 \\
\hline Magnesium $\left(\mathrm{cmoc} \mathrm{dm}^{3}\right)$ & 0.94 & 0.84 & 1.71 & 1.63 & 1.78 & 1.52 & 0.99 & 0.80 \\
\hline Aluminum $\left(\mathrm{cmoc} \mathrm{dm}^{3}\right)$ & 0.00 & 0.00 & 0.00 & 0.00 & 0.00 & 0.00 & 0.00 & 0.20 \\
\hline $\mathrm{H}+\mathrm{Al}\left(\mathrm{cmoc} \mathrm{dm}^{3}\right)$ & 3.05 & 2.14 & 0.00 & 3.05 & 4.29 & 3.71 & 2.80 & 3.96 \\
\hline Base sum $\left(\mathrm{cmoc} \mathrm{dm}^{3}\right)$ & 3.06 & 2.13 & 14.84 & 6.66 & 6.55 & 7.55 & 4.58 & 2.39 \\
\hline 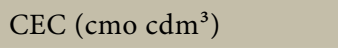 & 3.06 & 2.13 & 14.84 & 6.66 & 6.55 & 7.55 & 4.58 & 2.59 \\
\hline $\mathrm{CEC}$ at $\mathrm{pH} 7\left(\mathrm{cmoc} \mathrm{dm}^{3}\right)$ & 6.11 & 4.28 & 14.84 & 9.72 & 10.84 & 11.26 & 7.38 & 6.35 \\
\hline Base Saturation (\%) & 50.04 & 49.87 & 100.00 & 68.58 & 60.44 & 67.03 & 62.01 & 37.63 \\
\hline Aluminum saturation (\%) & 0.00 & 0.00 & 0.00 & 0.00 & 0.00 & 0.00 & 0.00 & 7.73 \\
\hline Organic matter $\left(\mathrm{g} \mathrm{kg}^{-1}\right)$ & 12.77 & 12.60 & 32.58 & 46.07 & 35.71 & 35.80 & 22.61 & 19.28 \\
\hline $\mathrm{pH}$ in water & 5.79 & 5.91 & 7.35 & 6.61 & 5.93 & 6.24 & 5.73 & 5.21 \\
\hline
\end{tabular}

The greenhouse has a galvanized aluminum structure, chapel ceiling, and is covered with a low density transparent polyethylene. The intermittent irrigation system consisted of six rows placed $1.5 \mathrm{~m}$ apart, with spray nozzles at each $1 \mathrm{~m}$, controlled by a device activated every three minutes, with an uninterrupted wet period of 15 seconds.

Two experiments were conducted to investigate vegetative propagation in sapucaia.

\subsection{Experiment 1: Rooting potential of sapucaia cuttings}

Sprouts were collected early in the morning from branches located in the nearer part of the tree base. For shorter trees with up to $4 \mathrm{~m}$ in height, we used an extendable tree pruner. For taller trees, with more than $13 \mathrm{~m}$ in height, the collection was done by a climber equipped with a hand pruning saw. In all trees, sprouts were collected on the lower branches, and the heights ranged according to the tree height (Table 1).

After collecting the branches, the lateral sprouts were removed, cut, and packed in polystyrene boxes. Water was hand-sprayed on the material until the step of cutting conducted in the next morning to keep vigor and turgescence due to the distance between the collection site and the experimental site.

Softwood and semi-hardwood cuttings were made from the branches of the trees M1C, M2C, M1A and M2A, M1J, and M2J (with a pair of halved leaves). From the trees M1L and M2L, besides softwood and semi-hardwood cuttings (with a pair of halved leaves), we also made hardwood cuttings (without leaves). Stem cuttings were prepared with $9-12 \mathrm{~cm}$ in length, with the lower part bevel-edged, and containing at least 4 buds.

Hardwood cuttings were removed from 2-year-old shoots, while softwood cuttings (apical portion) and semi-hardwood (basal portion) were taken from current-year shoots.

The cuttings were disinfested with $0.3 \%$ sodium hypochlorite for 5 minutes and washed in tap water. Then, the basal end of the cuttings was dipped approximately $3 \mathrm{~cm}$ into the dry powder of indole-3-butyric acid (inert talc) at the concentrations of $0 ; 2,000 ; 4,000 ; 6,000$; and $8,000 \mathrm{mg} \mathrm{kg}^{-1}$.

The different concentrations of IBA were prepared by mixing with powdered industrial talc ( $3 \mathrm{MgO} .4 \mathrm{SiO} 2 . \mathrm{H} 2 \mathrm{O})$. To prepare $10,000 \mathrm{mg}$ of the IBA-containing formula at 2,000; 4,000; 6,000; and 8,000 $\mathrm{mg} \mathrm{kg}^{-1}$, we dissolved 20, 40,60, and $80 \mathrm{mg}$ of pure IBA in pure ethyl alcohol, then mixed with the industrial talc to make up to $10,000 \mathrm{mg}$, and let the mixture dry at room temperature prior to use.

The cuttings were planted in plastic tubes $\left(123 \mathrm{~cm}^{3}\right)$ with the basal region inserted in the substrate. Sand sterilized at $127{ }^{\circ} \mathrm{C}$ in autoclave (steam saturated under pressure) for 60 minutes was used as substrate. To avoid sand leakage, a layer of approximately $2 \mathrm{~cm}$ of commercial substrate was placed on the bottom of the tube with slightly moistened decomposed pinus bark.

The experiment was arranged in a randomized block $(6 \times 2 \times 5)$ factorial design, with six parent trees, two types 
of cuttings (softwood and semi-hardwood), and five IBA concentrations $\left(0 ; 2,000 ; 4,000 ; 6,000\right.$; and $\left.8,000 \mathrm{mg} \mathrm{kg}^{-1}\right)$ for the trees M1C, M2C, M1A, M2A, M1J, and M2J. For trees M1L and M2L, we used a $2 \times 3 \times 5$ factorial design with two genotypes, three cutting types (softwood, semi-hardwood, and hardwood), and the same five IBA concentrations.

All treatments were arranged with four replications and 10 cuttings per plot due to the lacked material of some parent trees, the difficulty of collecting from tall trees and branches that not always had current year sprouts at the time of the collection.

After 120 days in the greenhouse, the results allowed us to analyze the following variables: percentage of dead cuttings, percentage of live cuttings, and percentage of cuttings with calli.

Data were analyzed by analysis of variance using Assistat 7.7 software (Silva \& Azevedo, 2002).

\subsection{Experiment 2: Induction of epicormic shoots in sectioned branches}

In this experiment, we used only branches from adult parent trees.

At the collection site, the pruned branches were cut to a size of approximately $60 \mathrm{~cm}$ in length, with different diameters, placed in polyethylene bags, and watered when necessary until arriving at the greenhouse. In the greenhouse, the branches had their ends protected with a plastic bag to avoid water loss and were placed on suspended garden beds, remaining there for 60 days.

After 60 days, the epicormic shoots formed on the branches would be used to produce cuttings to test their rooting capacity; however, not enough material was obtained because not all shoots reached the minimum size for use. Thus, we evaluated the total number of sprouts arisen from the branches collected from the parent trees.

\section{RESULTS AND DISCUSSION}

\subsection{Rooting potential of sapucaia cuttings}

There was an excessive leaf drop from softwood and semi-hardwood cuttings of adult trees seven days after the experiment set up. The leaf drop lasted up to 45 days after planting, when all the cuttings lost all their leaves. Then, 120 days after, there was no surviving cutting.

The softwood and semi-hardwood cuttings from the transitional trees, however, remained with leaves up to 90 days after planting, and at the end of the experiment (120 days) a softwood cutting of M1J parent treated with $4,000 \mathrm{mg} \mathrm{kg}^{-1}$ IBA remained alive, with leaf and root formation.
The early leaf loss of softwood cuttings from the adult trees were compared with cuttings removed from transitional trees, suggesting that the ontogenetic age of the parent plant affects leaf retention in softwood cuttings. This fact is related to the different physiological characteristics between parent plants due to changes in the apical meristems undergone by plants in the transition from the juvenile to the adult phase, which occur at distinct developmental and ontogenetic ages (Hartmann et al., 2011). A similar result was observed in the study by Neves et al. al. (2006) with the species Erythrina falcata, in which cuttings from juvenile material continued with leaves during the 80 days of the experiment, which did not occur with the softwood cuttings from adult trees.

In our study, early leaf drop may have compromised the survival of softwood and semi-hardwood cuttings, and, consequently, hampered root formation, since leaves are sites of auxin synthesis and carbohydrates. Therefore, leaf retention is expected to promote survival and root formation. Moreover, rooting and survival of leaf cuttings are likely to be related to the synthesis of phenolic compounds by the shoots (Pacheco \& Franco, 2008). These authors also report that certain phenolic compounds such as caffeic, catechol, and chlorogenic acids interact with auxins, inducing the initiation of the roots.

Studies on species like Tibouchina sellowiana (Bortolini et al., 2008; Nienow et al., 2010) and Erythrina falcata (Betanin \& Nienow, 2010) corroborate these results. In these studies, the high mortality of the cuttings or even the absence of rooting was related to early leaf drop, and greater percentages of survival and rooting to leaf retention for longer periods after the planting.

Despite the longer-lasting leaves, cuttings from transitional trees also did not survive after 120 days, except for one cutting that had a leaf. However, there was on average $80.5 \%$ of callus formation on the base of the softwood cuttings from the M1J parent tree. The effect of the concentrations used on callus percentage was not significant (Table 3 ).

Table 3. Percentage of cuttings with callus formation after 120 days in greenhouse, for the different concentrations of indole-3-butyric acid (IBA), on softwood cuttings from the parent tree M1J, 2015.

Concentration $\left(\mathrm{mg} \mathrm{Kg}^{-1}\right) \quad$ Callus formation (\%)

\begin{tabular}{|cc|}
\hline 0 & 77.50 \\
\hline 2,000 & 77.50 \\
\hline 4,000 & 82.50 \\
\hline 6,000 & 82.50 \\
\hline 8,000 & 82.50 \\
\hline Mean & 80.50 \\
\hline Coefficient of variation $(\%)$ & 13.03 \\
\hline
\end{tabular}


The treatment with IBA resulted in higher percentage of callus for some species such as Tectona grandis (teak) (Georgin et al., 2014). On the other hand, results obtained by Endres et al. (2007) and Leandro \& Yuyama (2008) for Caesalpinia echinata and Couepia edulis indicated that IBA did not increase or affect calli formation in cuttings of these species, as we observed for softwood cuttings from the parent tree M1J.

Hartmann et al. (2011) stated that, when a cutting is prepared, the cells of the cut surface are injured and a healing and regeneration process initiates. The effect of the injury at the base of the cuttings is beneficial for rooting, since it stimulates cell division and callus formation; and cell activity in the injured area is stimulated by increased respiratory rate and the contents of auxin, carbohydrate, and ethylene, resulting in root formation in the lesion margins.

In our study, we found that the softwood cutting of sapucaia with rooting formed callus near the cut. A similar finding was reported by Souza \& Lima (2005) and Barbosa et al., (2007) for cuttings of the species Spondias mombin and hybrids of Pyrus pyrifolia $\times$ Pyrus communis (pear), respectively, showing that adventitious roots were formed near the cambial region and on the callus tissue at the base of the cuttings.

The presence of a live and rooted cutting may indicate that the cuttings of transitional trees have the potential for root formation. However, since the greenhouse had no temperature control, temperature may have excessively increased at some point, which contributed to the death of cuttings that formed callus before root emergence.

Cuttings of Caesalpinia echinata Lam. (Brazil wood) and Sapium glandulatum (milktree) with callus may form roots in the long term if they remain in the rooting bed, as suggested by Endres et al. (2007) and Ferreira et al. (2009), respectively. It could have been tested in our study for softwood cuttings from the M1J parent tree of sapucaia, as well as a better control of temperature and moisture of the rooting place.

Regarding the hardwood cuttings of M1L and M2L parent trees, the statistical analysis showed no significant interaction between the factors genotype and concentration for the variable "survival percentage", indicating the independence of the factors. No significant differences for the genotypes used were observed in the variable analyzed and in the concentrations of AIB applied (Table 4).

No effect of IBA concentrations indicates that the survival of sapucaia hardwood cuttings is not related to the regulator, but actually to the type of cutting used. This indicates an absence of toxicity of the IBA at the concentrations used, since it is easily observed by the marked reduction in rooting or death of cuttings with increasing concentration of idol-3butyric acid, according to Heintze et al. (2015).

Table 4. Percentage of surviving cuttings after 120 days in greenhouse under different concentrations of indole-3-butyric acid (IBA) applied to hardwood cuttings from the parent trees M1L and M2L.

\begin{tabular}{|ccc|}
\hline Parent tree & Treatment & Survival (\%) \\
\hline M1L & 0 & 52.5 \\
M1L & 2,000 & 57.5 \\
M1L & 4,000 & 37.5 \\
\hline M1L & 6,000 & 57.5 \\
M1L & 8,000 & 57.5 \\
\hline M2L & 0 & 47.5 \\
\hline M2L & 2,000 & 42.5 \\
\hline M2L & 4,000 & 52.5 \\
M2L & 6,000 & 60.0 \\
\hline M2L & 8,000 & 52.5 \\
Mean & - & 52.75 \\
\hline
\end{tabular}

In general, the hardwood cuttings in our study showed a good survival rate, with a mean of $52.75 \%$, during the period evaluated. However, despite their survival, these cuttings did not present root or callus formation.

These results probably occur due to the higher lignification of the tissues of these cuttings, which provides a greater resistance to water loss, enabling their survival without rooting during the period in the greenhouse. However, higher lignification prevents root formation, since the maturation of plant tissues forms a physical barrier to root emergence by lignin deposition on cell walls and reduces the physiological ability to form root primordia (Xavier et al. 2013; Hartmann et al., 2011). Anatomical studies could confirm this hypothesis, since a continuous ring of sclerenchyma is formed between the phloem and the cortex outside the origin point of the adventitious roots with steam ageing and maturation, and these cells can hinder the rooting process (Hartmann et al., 2011).

The non-rooting of cuttings from adult trees may also have occurred due to the age of the M1L and M2L trees, with 27 years of age. In vegetative propagation of woody species, the rhizogenic capacity reduces with the increase of the plant ontogenetic age, as mature branches tend to have a lower concentration of auxin (Xavier et al., 2013). According to Xavier et al. (2013), the rooting inhibitor accumulation increase and phenolic levels reduce with tissue ageing, in addition to the existence of anatomical barrier of lignified tissue between the phloem and the cortex.

Santos et al. (2011) studied the rooting of hardwood cuttings from branches of adult trees and found that the 
species Tapirira guianensis, Sebastiania commersoniana, Erythrina falcata, Inga marginata, Inga vera, Magnolia ovata, Maclura tinctoria, and Casearia sylvestris had no adventitious rooting potential, even if maintained under favorable environmental conditions $\left(27^{\circ} \mathrm{C}\right.$ temperature and $85 \%$ relative humidity).

Many species that were initially considered difficult to propagate proved to be capable of vegetative propagation with the optimization of the nutritional status of the parent plant, the propagation environment, or of treatments such as auxin application (Atangana et al., 2006; Majada et al., 2011; Trueman et al., 2007; Wendling et al., 2010). These improvements may be applied in future studies aimed at the vegetative propagation of sapucaia.

Other techniques of asexual propagation can be evaluated such as grafting, air layering, or cuttings from more juvenile parent material that could be obtained from a mini-garden of seed-derived seedlings. In the last situation, however, we would not have had prior knowledge of genotype expression, regarding the superior characteristics of size and nut yield, which is important for the production of seedlings to plantations for nut production.

\subsection{Induction of epicormic shoots in sectioned branches}

Table 5 shows the efficiency of the technique for inducing sprout formation on branches collected from the parent trees M1C and M2C. A total of 70 and 74 sprouts emerged on branches from $\mathrm{M} 1 \mathrm{C}$ and $\mathrm{M} 2 \mathrm{C}$ trees, and 58 and 60 sprouts of branches from M1A and M2A trees.

Table 5 also shows that sprout formation on branches from the parent trees M1L and M2L was lower the other trees. This result may be related to the low genetic capacity of shoot formation of these parent trees, or to the fact that the branches were collected from the canopy at $7.5 \mathrm{~m}$ above the ground level. In some plants, especially woody plants, there is a juvenile gradient toward the base of the tree, since the meristems closer to the base were formed nearer to germination stage than those of apical regions (Hartmann et al., 2011).

Despite the emergence of enough sprouts for at least one treatment, these sprouts were not used due to their irregular size, most of them with less than $4 \mathrm{~cm}$ in length. It is also important to inform that these shoots have no great longevity, since the mortality rate was almost $100 \%$ after 60 days of emergence. A similar result was found in a study by Wendling et al. (2009), which showed a high mortality of sprouts induced in adult trees of Araucaria angustifolia after120 days, besides the low sprout emergence.
Juvenile propagules of adult plants are important to enable the vegetative propagation of species of difficult rooting, since rejuvenation may be a viable strategy when adult shoots do not root or when they present low rooting percentage and vigor (Rickli et al., 2015).

Table 5. Average number of sprouts emerged per sectioned branch $(60 \mathrm{~cm})$ of the parent trees M1C, M2C, M1A, M2A, M1L, and M2L, after 45 days in greenhouse.

\begin{tabular}{|cc|}
\hline Parent tree & Sprout/branch (mean) \\
\hline M1C & 7.0 \\
M2C & 7.4 \\
M1A & 5.8 \\
M2A & 6.0 \\
M1L & 0.2 \\
M2L & 0.3 \\
\hline
\end{tabular}

Our study presents promising findings, since they showed that the vegetative rescue is a feasible technique for inducing sprouts. The problem of insufficient material can be overcome by collecting a greater number of branches, or by using these branches to test other vegetative propagation methods, with smaller propagule sizes, as in in vitro propagation.

\section{CONCLUSIONS}

Softwood and semi-hardwood stem cuttings of transitional and adult sapucaia trees have the survival compromised with the early leaf drop, being unable to demonstrate their rooting potential.

The concentrations of indole-3-butyric acid do not affect callus formation of softwood cuttings with leaves and the survival of hardwood stem cuttings from adult parent trees.

The vegetative rescue is a feasible technique for inducing sprouts; however, their rooting potential needs to be evaluated.

\section{ACKNOWLEDGEMENTS}

To Fundação de Amparo à Pesquisa e Inovação do Espírito Santo (Fapes), for the resources provided to the performance of our study, and to Coordenação de Aperfeiçoamento de Pessoal de Nível Superior (Capes) for the funding support.

\section{SUBMISSION STATUS}

Received: 8 June 2018

Accepted: 7 Nov. 2018

Associate editor: José Carlos Arthur Junior

(D) 0000-0002-4161-8822 


\section{CORRESPONDENCE TO}

\section{Elzimar de Oliveira Gonçalves}

Universidade Federal do Espírito Santo (UFES), Av. Governador Lindemberg, 340, CEP 29550-000, Jerônimo Monteiro, ES, Brasil e-mail: elzimarog@yahoo.com.br

\section{FINANCIAL SUPPORT}

Fundação de Amparo à Pesquisa e Inovação do Espírito Santo (Fapes) (Award number: 676540096/14 and TO 400, $\mathrm{R} \$ 41.000,00)$. Coordenação de Aperfeiçoamento de Pessoal de Nível Superior (Capes) (Funding code 001).

\section{REFERENCES}

Alvarez VVH, Novaes RF, Barros NF, Cantarutti RB, Lopes AS. Interpretação dos resultados das análises de solos. In: Ribeiro AC, Guimaraes PTG, Alvarez VVH, editors. Recomendação para o uso de corretivos e fertilizantes em Minas Gerais: 5. aproximação. Viçosa: Comissão de Fertilidade do Solo do Estado de Minas Gerais; 1999. p. 25-32.

Atangana AR, Tchoundjeu Z, Asaah EK, Simons AJ, Khasa DP. Domestication of Allanblackia floribunda: amenability to vegetative propagation. Forest Ecology Management 2006; 237(1-3): 246-251. 10.1016/j.foreco.2006.09.081

Barbosa W, Pio R, Feldberg NP, Chagas EA, Veiga RFA. Enraizamento de estacas lenhosas de pereira tratadas com AIB e mantidas em ambiente de estufa tipo B.O.D. e de telado. Revista Brasileira de Fruticultura 2007; 29(3): 589-594. 10.1590/S0100-29452007000300033

Betanin L, Nienow AA. Propagação vegetativa da corticeira-da-serra (Erythrina falcata Benth.) por estaquia caulinar e foliar. Semina 2010; 31(4): 871-880. 10.5433/1679-0359.2010v31n4p871

Bortolini MF, Zuffellato-Ribas KC, Koehler HS, Carpanezzi AA, Deschamps C, Oliveira MC, Bona C et. al. Tibouchina sellowiana (Cham.) Cogn.: enraizamento, anatomia e análises bioquímicas nas quatro estações do ano. Ciência Florestal 2008; 8(2): 159-171. $10.5902 / 19805098454$

Carvalho IMM, Queir LD, Brito LF, Santos FA, Bandeira AVM, Souza AL, Queiroz JH. Caracterização química da castanha de sapucaia (Lecythis pisonis Cambess) da região da zona da mata mineira. Bioscience Journal 2012; 28(6): 971-977.

Denadai SMS, Hiane PA, Marangoni S, Baldasso PA, Miguel AMRO, Macedo MLR. In vitro digestibility of globulins from sapucaia (Lecythis pisonis Camb.) nuts by mammalian digestive proteinases. Ciência e Tecnologia de Alimentos 2007; 27(3): 535-543. 10.1590/ S0101-20612007000300018

Endres L, Marroquim PMG, Santos CM, Souza NNF. Enraizamento de estacas de Pau-Brasil (Caesalpinia echinata Lam.) tratadas com ácido indol butírico e ácido naftaleno acético. Ciência Rural 2007; 37(3): 886-889. 10.1590/S0103-84782007000300046

Ferreira BGA, Zuffellato-Ribas KC, Carpanezzi AA, Tavares FR, Koehler HS. Metodologias de aplicação de AIB no enraizamento de estacas semilenhosas de Sapium glandulatum (Vell.) Pax. Revista Brasileira de Plantas Medicinais 2009; 11(2): 196-201. 10.1590/ S1516-05722009000200014
Garay I, Folz J, Del Piero N, Carolina K. Espécies arbóreas para reflorestamento: restauração solidária de floresta atlântica. Cariacica: Instituto Estadual de Meio Ambiente e Recursos Hídricos; 2012.

Georgin J, Bazzoti R, Perrando E. Indução ao enraizamento de estacas de teca (Tectona grandis l.f). Electronic Journal of Management, Education and Environmental Technology 2014; 18(3): 1246-1256. 10.5902/2236117014537

Hartmann HT, Kester DE, Davies FT Jr, Geneve RL. Plant propagation: principles and practices. 8 th ed. New Jersey: PrenticeHall; 2011.

Heintze W, Petry HB, Schwarz SF, Souza PV, Schafer G. Propagação de Thunbergia mysorensis (Wight) por estaquia. Ciência Rural 2015; 45(8): 1455-1458. 10.1590/0103-8478cr20140764

Inhetvin $\mathrm{T}$, editor. Relatório de estudo: cadeias de valor da sociobiodiversidade no corredor central da Mata Atlântica (Bahia e Espírito Santo). Salvador; 2010.

Leandro RC, Yuyama K. Enraizamento de estacas de castanha-decutia com uso de ácido indolbutírico. Acta Amazonica 2008; 38(4): 597-602. 10.1590/S0044-59672008000400001

Lima JSS, Silva SA, Oliveira RB, Cecílio RA, Xavier AC. Variabilidade temporal da precipitação mensal em Alegre - ES. Revista Ciência Agronômica 2008; 39(2): 327-332.

Lorenzi H. Árvores brasileiras: manual de identificação e cultivo de plantas arbóreas nativas do Brasil. Nova Odessa: Instituto Plantarum de Estudos da Flora; 2008. 384 p.

Majada J, Martínez-Alonso C, Feito I, Kidelman A, Aranda I, Alía R. Mini-cuttings: an effective technique for the propagation of Pinus pinaster. New Forests 2011; 41(3): 399-412. 10.1007/ s11056-010-9232-x

Neves TS, Carpanezzi AA, Zuffellato-Ribas KC, Marenco RA. Enraizamento de corticeira-da-serra em função do tipo de estaca e variações sazonais. Pesquisa Agropecuária Brasileira 2006; 41(12): 1699-1705

Nienow AA, Chura G, Petry C, Costa C. Enraizamento de estacas de quaresmeira em duas épocas e concentrações de ácido indolbutírico. Revista Brasileira de Agrociência 2010; 16(1-4): 139-142. 10.18539/ CAST.V16I1-4.2022

Pacheco JP, Franco ETH. Ácido indolbutírico em diferentes diâmetros na estaquia de Luehea divaricata. Ciência Rural 2008; 38(6): 1624-1629. 10.1590/S0103-84782008000600020

Rickli HC, Bona C, Wendling I, Koehler H S, Zuffellato-Ribas KC. Origem de brotações epicórmicas e aplicação de ácido indolilbutírico no enraizamento de estacas de Vochysia bifalcata Warm. Ciência Florestal 2015; 25(2): 385-393. 10.5902/1980509818457

Rizzini CT. Árvores e madeiras uteis do Brasil: manual de dendrologia brasileira. São Paulo: E. Blucher; 1971. 294 p.

Santos JP, Davide AC, Teixeira LAF, Melo AJS, Melo LA. Enraizamento de estacas lenhosas de espécies florestais. Cerne 2011; 17(3): 293-301. 10.1590/S0104-77602011000300002

Sauer M, Robert S, Kleine-Vehn J. Auxin: simply complicated. Journal of Experimental Botany 2013; 64(9): 2565-2577. 10.1093/jxb/ert139

Scaloppi EJ Jr, Martins ABG. Estaquia em Anonas. Revista Brasileira de Fruticultura 2014; 36(1): 147-156. 10.1590/S0100-29452014000500018 
Silva FAS, Azevedo CAV. Versão do programa computacional Assistat para o sistema operacional Windows. Revista Brasileira de Produtos Agroindustriais 2002; 4(1): 71-78.

Silva SR, Rodrigues KFD, Scarpare Filho JA. Propagação de árvores frutiferas. Piracicaba: ESALQ; 2011.

Smith NP, Mori SA, Prance GT. Lecythidaceae. In: Jardim Botânico do Rio de Janeiro. Lista de espécies da Flora do Brasil [Internet]. 2014 [cited 2016 June 14]. Available from: https://bit.ly/2WstJXn

Souza FX, Lima RN. Enraizamento de estacas de diferentes matrizes de cajazeira tratadas com ácido indolbutírico. Revista Ciência Agronômica 2005; 36(2): 189-194.

Trueman SJ, Richardson DM. In vitro propagation of Corymbia torelliana x C. citriodora (Myrtaceae) via cytokinin-free node culture. Australian Journal of Botany 2007; 55(4): 471-481. 10.1071/BT06163

Wendling I, Dutra LF, Bettio G, Hansel F. Indução de brotações epicórmicas ortotrópicas para a propagação vegetativa de árvores adultas de Araucaria angustifolia. Agronomía Costarricense 2009; 33(2): 309-319.

Wendling I, Brondani GE, Dutra LF, Hansel FA. Mini-cuttings technique: a new ex vitro method for clonal propagation of sweetgum. New Forests 2010; 39(3): 343-353. 10.1007/s11056-009-9175-2

Wickens GE. Management issues for development of non-timber forest products [Internet]. Unasylva 1991 [cited 2016 Sept. 11] 42(165): 3-8. Available from: https://bit.ly/2QAOTi2

Xavier A, Wendling I, Silva RL. Silvicultura clonal: princípios e técnicas. 2nd ed. Viçosa: Editora UFV; 2013. 